\title{
Egg white hydrolysate and peptide reverse insulin resistance associated with tumor necrosis factor-a (TNF-a) stimulated mitogen- activated protein kinase (MAPK) pathway in skeletal muscle cells
}

\author{
Myoungjin Son ${ }^{1}$. Jianping $\mathrm{Wu}^{1,2}$
}

Received: 8 February 2018 / Accepted: 11 June 2018 / Published online: 28 June 2018

(c) The Author(s) 2018

\begin{abstract}
Purpose Excessive formation of tumor necrosis factor- $\alpha$ (TNF- $\alpha$ ), a pro-inflammatory cytokine, has been implicated in the development of insulin resistance in obesity and type-2 diabetes. In skeletal muscle, chronic exposure to TNF- $\alpha$ impairs insulin-stimulated glucose uptake and insulin signaling. The aim of this study is to investigate the effects of enzymatic egg white hydrolysate $(\mathrm{EWH})$ and its responsible peptide, IRW, on TNF- $\alpha$-induced insulin resistance and the underlying molecular mechanisms using rat skeletal muscle cells (L6 cells).

Methods Insulin resistance was induced by treating L6 cells with $5 \mathrm{ng} / \mathrm{ml}$ TNF- $\alpha$ for $24 \mathrm{~h}$. Effects of EWH and IRW on glucose uptake were detected by glucose uptake assay, glucose transporter 4 (GLUT4) translocation by immunofluorescence, and western blot, while insulin-signaling pathway and mitogen-activated protein kinase (MAPK) pathway were investigated using western blot.

Results Adding both EWH and IRW significantly improved glucose uptake in TNF- $\alpha$-treated cells, increased activation of insulin receptor substrate (IRS-1) tyrosine residue and protein kinase B (Akt), whereas decreased activation of IRS-1 serine residue. In addition, TNF- $\alpha$-induced activation of p38-mitogen-activated protein kinase (p38) and c-Jun N-terminal kinases (JNK) $1 / 2$ were decreased by either EWH or IRW treatment.

Conclusion EWH and IRW improve impaired insulin sensitivity by down-regulating the activation of p38 and JNK1/2 in TNF- $\alpha$-treated skeletal muscle cells.
\end{abstract}

Keywords Insulin resistance $\cdot$ Skeletal muscle cells $\cdot$ Egg white protein hydrolysate $\cdot$ IRW $\cdot$ Insulin signaling

\section{Introduction}

Metabolic syndrome is represented by a group of interrelated disorders, including obesity, hyperglycemia, hyperlipidemia, and hypertension [1]. It is also a significant risk factor for cardiovascular disease and increased morbidity and mortality [2]. The incidence of metabolic syndrome is rapidly increasing worldwide, becoming a major public and clinical problem [3]. Insulin resistance is a major underlying mechanism responsible for metabolic syndrome [4].

Jianping $\mathrm{Wu}$

jwu3@ualberta.ca

1 Department of Agricultural, Food and Nutritional Science, University of Alberta, Edmonton, AB T6G 2P5, Canada

2 Cardiovascular Research Centre, University of Alberta, Edmonton, AB T6G 2P5, Canada
Although pancreatic $\beta$-cell dysfunction is another feature for development of type 2 diabetes, insulin resistance is regarded as primary factor to initiate the development of hyperglycemia prior to $\beta$-cell failure [5, 6]. Since skeletal muscle is the predominant site of insulin-stimulated glucose uptake, numerous recent studies have focused on discovering therapeutic compound to improve insulin resistance in skeletal muscle [7].

In normal skeletal muscle metabolism, insulin stimulates auto-phosphorylation of insulin receptor on tyrosine residues and consequent phosphorylation of insulin receptor substrates 1 and 2 (IRS-1 and IRS-2). This results in the activation of phosphatidylinositol 3-kinase (PI3K) and protein kinase $\mathrm{B}(\mathrm{Akt})$ allowing glucose transporter protein 4 (GLUT4) storage vesicles to move to the plasma membrane for glucose uptake [8]. After uptake, glucose is phosphorylated by hexokinase, and then stored as glycogen or enters into mitochondria for glucose oxidation through the 
tricarboxylic acid (TCA) cycle and electron transport system [9]. In insulin resistance state, insulin signaling is impaired, which results in decreased capacity of insulin to stimulate the translocation of GLUT4, whereas the GLUT4 protein content is unchanged [10].

TNF- $\alpha$ is a pro-inflammatory cytokine that plays a key role in the mediation of immune response as a multi-functional regulator of inflammation, cell apoptosis, cytotoxicity, and production of other cytokines [11]. Multiple studies revealed that excessive TNF- $\alpha$ concentrations have been implicated in the development of insulin resistance in obesity and type 2 diabetes [12-15]. In skeletal muscle, chronic exposure to TNF- $\alpha$ impairs insulin-stimulated glucose uptake and GLUT4 translocation by increasing the phosphorylation of Ser residue of IRS-1 while decreasing the phosphorylation of Akt [16-20]. The molecular mechanism underlying TNF- $\alpha$-mediated insulin resistance is well recognized. TNF- $\alpha$-activated oxidative and pro-inflammatory pathways are mediated by $\mathrm{p} 38$-mitogen-activated protein kinase (p38), c-Jun N-terminal kinases (JNK), and extracellular signal-regulated protein kinases 1 and 2 (ERK1/2) [16, 17]; inhibitor of p38 completely restored insulin-dependent glucose uptake and insulin-signaling pathway [16]. In addition, TNF- $\alpha$ was shown to suppress insulin sensitivity by the inactivation of the key energy sensor, $5^{\prime}$ adenosine monophosphate-activated protein kinase (AMPK), via the transcriptional upregulation of protein phosphatase $2 \mathrm{C}$ (PP2C) [20].

There has been an explosion of scientific research in regard of food-derived bioactive protein peptides [21]. Our previous research has identified three egg white protein ovotransferrin-derived ACE-inhibitory peptides, IRW, IQW, and LKP [22-29]. Among them, IRW showed anti-inflammatory and anti-oxidant ability in vitro and in vivo [25-29]. Our recent study also further suggested that IRW improved insulin resistance in angiotensin II-treated L6 skeletal muscle cells [30]. While these individual peptides possess strong bioactivities, the commercialization is still limited due to the unavailability of technologies and high cost of purification techniques. Hence, there is a great therapeutic applicability of using enzymatic hydrolysate of whole egg white. Our previous research has shown that egg white hydrolysate (EWH) prepared by thermolysin and pepsin-reduced blood pressure, improved vascular relaxation, and reduced aortic angiotensin II receptors 1 (AT1R) expression in spontaneously hypertensive rats (SHR) [31]. Our recent studies also further suggested that EWH might have a beneficial effect on insulin sensitivity and metabolic syndrome. EWH treatment on 3T3-F442A pre-adipocytes increased the cell differentiation, insulin-signaling pathway, and inhibited inflammatory markers such as cyclooxygenase-2 (COX-2) and JNK [32].

Although commercially produced EWH has been shown to improve glucose homeostasis [33], its underlying mechanism as well as the peptides responsible for the action have not been fully investigated. Herein, we investigated the effect of EWH and egg white-derived peptide, IRW, on TNF$\alpha$-induced insulin resistance and its underlying molecular mechanism by testing glucose uptake, GLUT4 translocation, and insulin-signaling pathway using rat skeletal muscle cells (L6). To induce insulin resistance, we incubated L6 myotubes with TNF- $\alpha$ for $24 \mathrm{~h}$. The role of EWH and IRW in preventing TNF- $\alpha$-induced insulin resistance was studied by co-incubation of TNF- $\alpha$ in the presence of EWH or IRW.

\section{Materials and methods}

\section{Materials}

TNF- $\alpha$, insulin, dithiothreitol (DTT), and Triton-X-100 were from Sigma-Aldrich (St Louis, MO, USA). Dulbecco's modified Eagle medium (DMEM), fetal bovine serum (FBS), and antibiotic-antimycotic solution and horse serum were purchased from Gibco/Invitrogen (Carlsbad, CA, USA). Dihydroethidium (DHE), Hoechst 33342, was purchased from Thermo Fisher Scientific (Thermo Fisher Scientific, Burlington, Canada). IRW was synthesized by Genscript (Piscataway, NJ, USA). Peptide sequence and purity (99.8\%) were validated by HPLC-MS/MS.

\section{Antibodies}

Rabbit monoclonal primary antibodies against phosphoinsulin receptor 1 (Tyr632 and Ser307), and insulin receptor 1 and p38 were obtained from Santa Cruz Biotechnology Inc (SantaCruz, CA, USA). Rabbit monoclonal primary antibody against GLUT4 and mouse monoclonal primary antibody against $\alpha$-tubulin and phospho-p38 were bought from Abcam (Cambridge, MA, USA). Rabbit monoclonal primary antibody against phospho-Akt (Ser473), Akt was bought from Cell Signaling Technology Inc. (Danvers, MA, USA). Goat anti-rabbit IRDye 680RD secondary antibody or donkey anti-mouse $800 \mathrm{CW}$ secondary antibody was purchased from Licor Biosciences (Lincoln, NE, USA). Rabbit monoclonal primary antibody against phospho JNK and mouse monoclonal primary antibody against JNK was purchased from RD system (Minneapolis, MN, USA).

\section{Preparation of egg white hydrolysate (EWH)}

Hydrolysis of egg white was carried out according to our previous method [22]. EWH was desalted with $50 \%$ acetonitrile/deionized water using Sep-Pak C18 cartridges (product 
\#: WAT043345, Waters, Ontario, Canada) to remove salts in the hydrolysate for using in cell experiments.

\section{Cell culture}

Rat-derived L6 myoblasts were obtained from AmericanType Culture Collection (Manassas, VA; ATCC_numbers: CRL-1458). The cells were grown in DMEM supplemented with $10 \%$ FBS and $1 \%$ v/v antibiotic-antimycotic solution $(10,000$ units $/ \mathrm{ml}$ penicillin $\mathrm{G}, 10 \mathrm{mg} / \mathrm{ml}$ streptomycin, and $25 \mathrm{mg} / \mathrm{ml}$ amphotericin B) at $5 \% \mathrm{CO}_{2}$ and $37^{\circ} \mathrm{C}$ until they reached $80 \%$ confluence. For further differentiation, the cells were cultured in DMEM containing $2 \%$ horse serum for 6-7 days. The media were changed every $48 \mathrm{~h}$ and cells were used at the stage of myotubes $(60-70 \%)$ when GLUT4 expression is the highest [34].

\section{Glucose uptake assay}

Glucose uptake assay was examined by the procedure described previously $[35,36]$ with slight modifications. Briefly, L6 myoblasts $\left(5 \times 10^{4}\right.$ cells/well) were subcultured into Nunc 24-place multiwell plates and grown for 9-10 days until they formed myotubes. The myotubes were incubated with $5 \mathrm{mg} / \mathrm{ml}$ of EWH or $100 \mu \mathrm{M}$ of IRW in serum-free DMEM $2 \mathrm{~h}$. Next, $5 \mathrm{ng} / \mathrm{ml}$ TNF- $\alpha$ was co-incubated for another $24 \mathrm{~h}$ to induce insulin resistance as described previously by Alvaro et al. [16] with a slight modification.

Next, the myotubes were kept for $2 \mathrm{~h}$ in Krebs-Henseleit buffer ( $\mathrm{pH} 7.4$ ) containing $0.1 \%$ bovine serum albumin (BSA), $10 \mathrm{mM}$ Hepes, and $2 \mathrm{mM}$ sodium pyruvate (KHH buffer). The myotubes were then cultured in KHH buffer containing $11 \mathrm{mM}$ glucose in the absence or the presence of $1 \mu \mathrm{M}$ of insulin for another $4 \mathrm{~h}$. Glucose concentrations in KHH buffer were determined with Glucose CII-Test kit (Wako Pure Chemical Industries, Ltd., Osaka, Japan) and the amounts of glucose consumed were calculated from the differences in glucose concentrations between before and after culture.

\section{Insulin-signaling pathway assay}

The L6 myotubes were incubated with $5 \mathrm{mg} / \mathrm{ml}$ of EWH or $100 \mu \mathrm{M}$ of IRW in serum-free DMEM for $2 \mathrm{~h}$, followed by treatment with $5 \mathrm{ng} / \mathrm{ml} \mathrm{TNF-} \alpha$ for different time conditions. To detect the total and phosphorylated proteins of the insulin-signaling pathway, the myotubes were kept for $2 \mathrm{~h}$ in KHH buffer ( $\mathrm{pH} 7.4$ ) and then incubated in KHH buffer containing $11 \mathrm{mM}$ glucose in the absence or the presence of $1 \mu \mathrm{M}$ insulin for $30 \mathrm{~min}$. At the end of incubation, L6 myotubes were lysed in boiling hot Laemmle's buffer containing $50 \mathrm{mM}$ DTT and $0.2 \%$ Triton-X-100 to prepare samples for western blotting. To extract the protein from cell membrane, a Mem-PER ${ }^{\mathrm{TM}}$ Plus Membrane Protein Extraction Kit (Thermo Fisher Scientific) was used. Briefly, cells were washed with cell wash solution and centrifuged at $300 \times \mathrm{g}$ for $5 \mathrm{~min}$. After discarding the supernatant, cells were resuspended and incubated with permeabilization buffer at $4{ }^{\circ} \mathrm{C}$. Next, permeabilized cells were centrifuged for $15 \mathrm{~min}$ at $16,000 \times g$. The supernatant containing cytosolic proteins was transferred into a new tube and the pellet was incubated with solubilization buffer at $4{ }^{\circ} \mathrm{C}$ for $30 \mathrm{~min}$. After centrifuging for $15 \mathrm{~min}$ at $16,000 \times g$, the supernatant containing solubilized membrane and membrane-associated proteins was transferred to a new tube for western blotting analysis. The cell lysates were then run in 9\% sodium dodecyl sulfate polyacrylamide gel electrophoresis (SDS-PAGE), transferred to nitrocellulose membranes, and immunoblotted with primary antibodies. After incubating with secondary antibodies, protein bands were detected by Licor Odyssey BioImager (Licor Biosciences, NE, USA) and quantified by densitometry using Image Studio Lite 5.2.

\section{Immunofluorescence}

L6 myotubes were incubated with $5 \mathrm{mg} / \mathrm{ml}$ of EWH or $100 \mu \mathrm{M}$ of IRW $2 \mathrm{~h}$ prior to treatment with $5 \mathrm{ng} / \mathrm{ml}$ TNF- $\alpha$ for $24 \mathrm{~h}$. The myotubes were then incubated for $2 \mathrm{~h}$ in KHH buffer and then kept in KHH buffer containing $11 \mathrm{mM}$ glucose in the absence or the presence of $1 \mu \mathrm{g}$ of insulin for $30 \mathrm{~min}$. The myotubes were fixed in $3.75 \%$ paraformaldehyde. To selectively stain the proteins on cell membranes, the cells were not permeabilized. After washing twice with PBS, cells were blocked with $1 \%$ BSA in PBS for $1 \mathrm{~h}$ and incubated with anti-GLUT4 primary antibody overnight at $4{ }^{\circ} \mathrm{C}$. After washing three times with PBS, cells were treated with Alexa Fluor 546 conjugated goat anti-rabbit secondary antibody for $1 \mathrm{~h}$ at room temperature. The cell nuclei were stained with Hoechst 33342 dye from molecular probes. Finally, after washing three times with PBS, cells were examined with an EVOS FL Auto Cell Imaging System (Thermo Fisher Scientific). All images presented are $100 \times$ magnification.

\section{Statistical analysis}

All data are presented as the mean \pm SEM. The data were evaluated by IBM SPSS version 22. Differences between the mean values were assessed using one- or two-way ANOVA, followed by Tukey multiple comparisons test if applicable. Statistical significance was considered for values of $p<0.05$. 


\section{Results}

\section{Effect of EWH or IRW on glucose uptake in L6 myotubes}

To investigate the effect of EWH or IRW on insulin-independent glucose uptake in L6 myotubes, EWH or IRW was incubated with glucose-KHH buffer for $4 \mathrm{~h}$ in the absence of insulin. Neither EWH nor IRW stimulated basal glucose uptake (Fig. 1a). To test the possible insulin-sensitizing effect of peptides, EWH or IRW was incubated with insulin for $4 \mathrm{~h}$ and no significant changes in glucose uptake were detected in the presence of EWH or IRW (Fig. 1b).

TNF- $\alpha$ has been reported to decrease insulin-stimulated glucose uptake in skeletal muscle [16, 19, 20]. Therefore, we detected whether EWH or IRW can protect the action of insulin from TNF- $\alpha$ treatment. The myotubes were incubated with EWH $(1.25,2.5$, and $5 \mathrm{mg} / \mathrm{ml})$ or IRW $(25,50$,
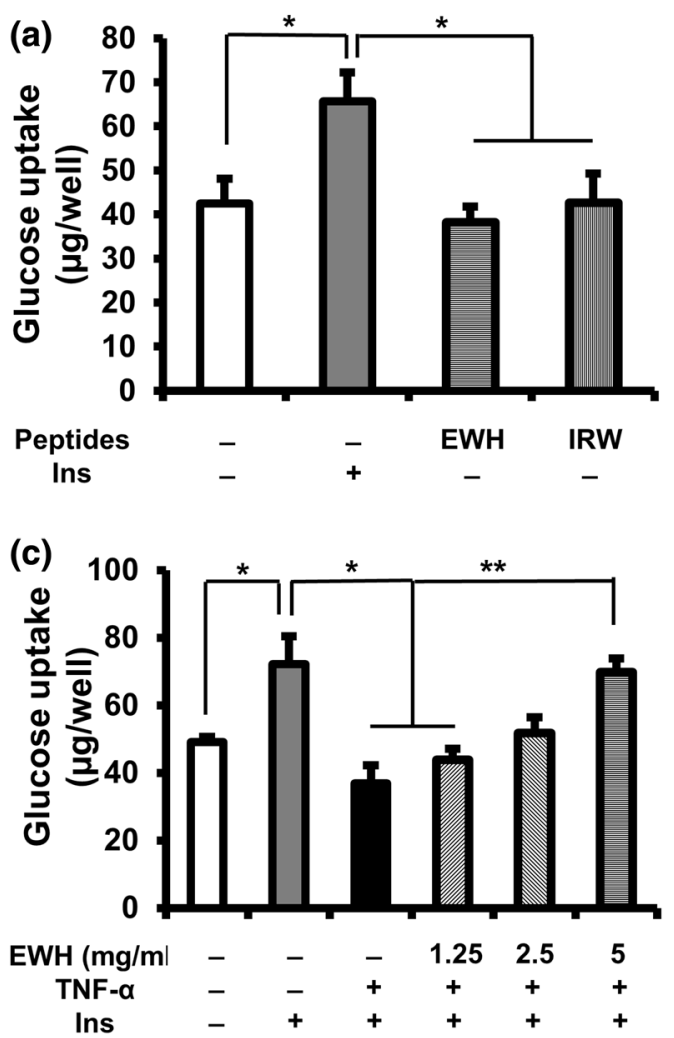

Fig. 1 Effects of EWH or IRW on glucose uptake in L6 myotubes. Effects of EWH or IRW on glucose uptake in the absence or the presence of insulin $(\mathbf{a}, \mathbf{b})$. The myotubes were preincubated in 24-place multiwell plates in Krebs-Henseleit-Hepes buffer (KHH buffer) without glucose for $2 \mathrm{~h}$. They were then incubated in KHH buffer containing $11 \mathrm{mM}$ glucose without or with insulin and $5 \mathrm{mg} / \mathrm{ml}$ of EWH or $100 \mu \mathrm{M}$ of IRW for $4 \mathrm{~h}$. Effects of EWH or IRW on insulinstimulated glucose uptake in TNF- $\alpha$-treated L6 myotubes $(\mathbf{c}, \mathbf{d})$. The myotubes were incubated with EWH $(1.25,2,5$, and $5 \mathrm{mg} / \mathrm{ml})$ or IRW and $100 \mu \mathrm{M}$ ) for $2 \mathrm{~h}$ followed by the co-incubation with TNF- $\alpha$ for $24 \mathrm{~h}$. TNF- $\alpha$ significantly decreased insulinstimulated glucose uptake by $50 \%$ compared to the one with insulin alone (Fig. 1c, d). However, pre-incubation of EWH $(5 \mathrm{mg} / \mathrm{ml})$ or IRW $(100 \mu \mathrm{M})$ prior to TNF- $\alpha$ treatment significantly restored the decreased glucose uptake.

\section{Effect of EWH or IRW on insulin-signaling pathway in TNF-a-treated L6 myotubes}

To investigate whether EWH or IRW can stimulate insulin signaling in the absence or the presence of insulin, the phosphorylation of Akt was detected. The treatment of both EWH and IRW did not affect the Akt activation in the absence or the presence of insulin as expected from the results of glucose uptake (Fig. 2a, b).

It is well documented that TNF- $\alpha$ impairs insulin-signaling pathway [16-19]. Consistent with the literatures, our results showed that TNF- $\alpha$ significantly reduced the
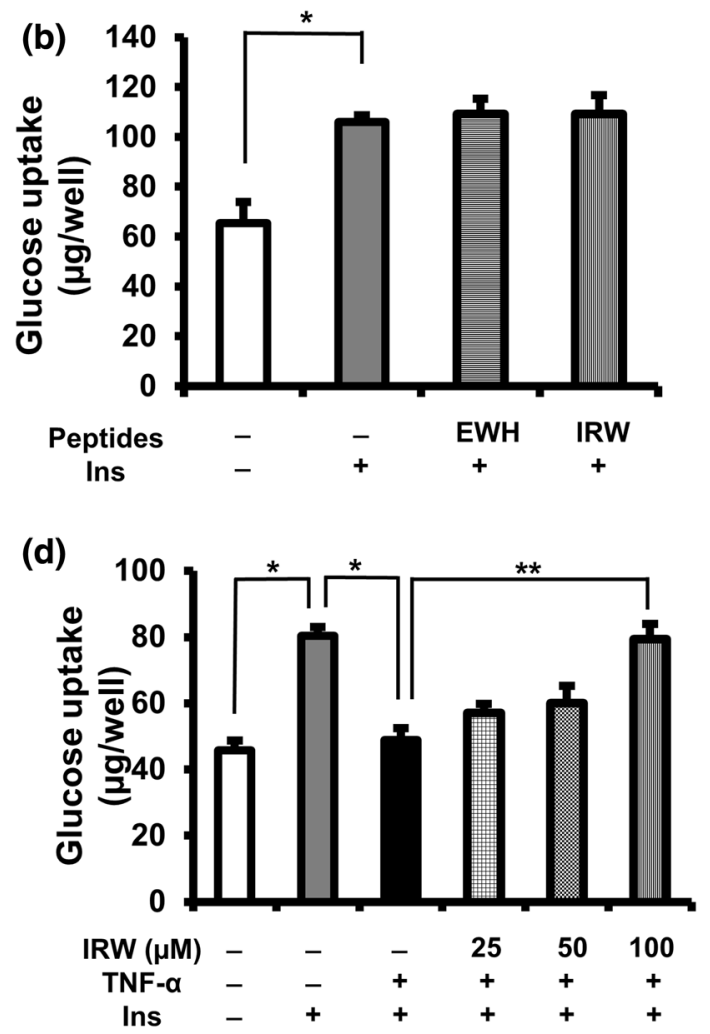

$(25,50$, and $100 \mu \mathrm{M}) 2 \mathrm{~h}$ prior to the treatment of $5 \mathrm{ng} / \mathrm{ml}$ of TNF- $\alpha$ for $24 \mathrm{~h}$. Next, the myotubes were kept for $2 \mathrm{~h}$ in KHH buffer. The myotubes were then cultured in $\mathrm{KHH}$ buffer containing $11 \mathrm{mM}$ glucose in the absence or the presence of $100 \mathrm{~nm}$ of insulin for another $4 \mathrm{~h}$, and then, the glucose uptake was measured using a Glucose CIITest Kit. Each value represents the mean \pm SEM of five independent experiments. Single asterisk indicates $p<0.05$ as compared to insulin alone. Double asterisk indicates $p<0.05$ as compared to the insulin and TNF- $\alpha$ 
(a)

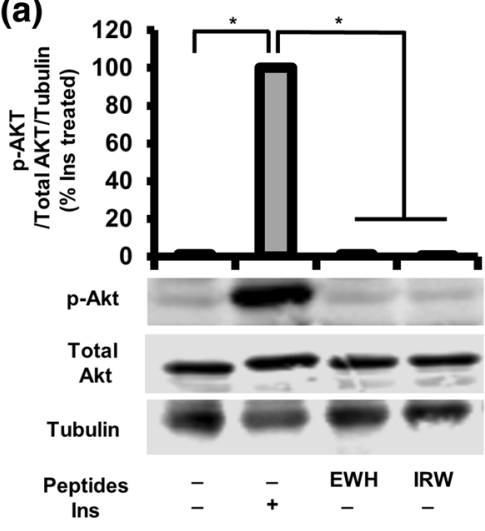

(b)

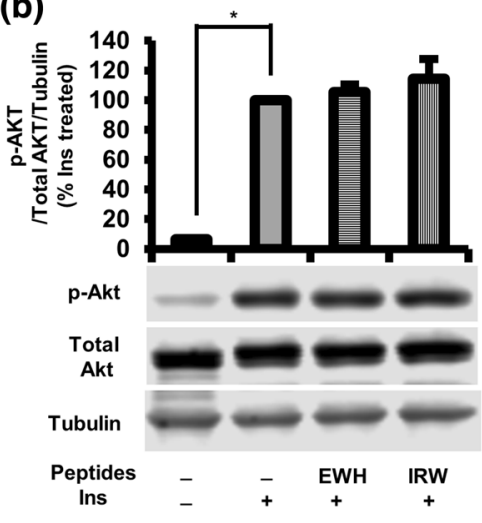

(c)

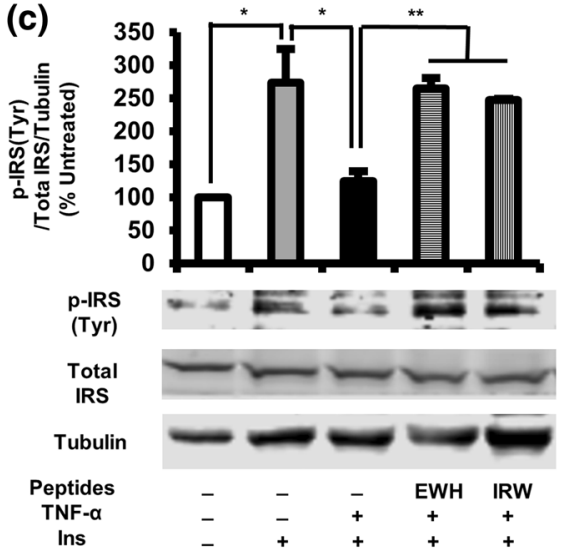

(d)

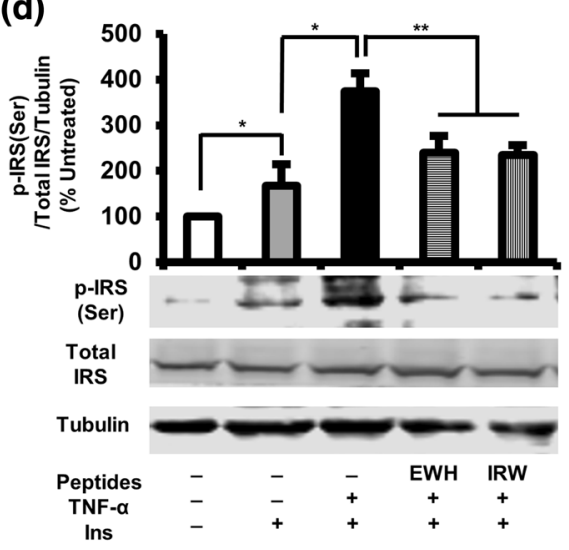

(e)

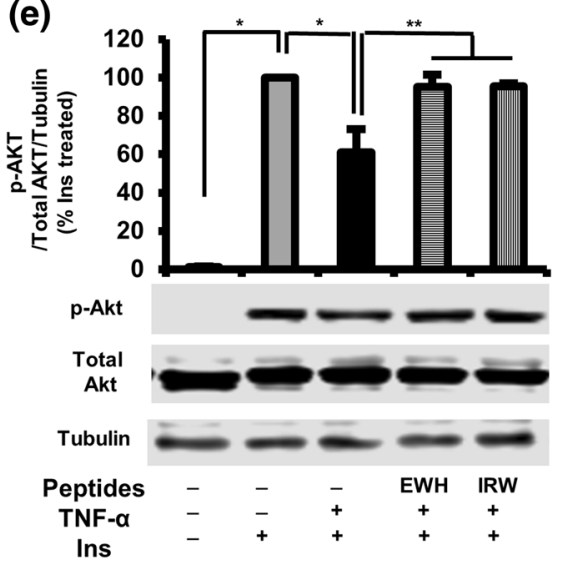

Fig. 2 Effects of EWH or IRW on insulin-signaling pathway in L6 myotubes. Effects of EWH or IRW on insulin signaling in the absence or the presence of insulin $(\mathbf{a}, \mathbf{b})$. The myotubes were treated with $5 \mathrm{mg} / \mathrm{ml}$ of EWH or $100 \mu \mathrm{M}$ of IRW for $2 \mathrm{~h}$ followed by treatment with $100 \mathrm{~nm}$ of insulin for $30 \mathrm{~min}$. Effects of EWH or IRW on insulin-signaling pathway in TNF- $\alpha$-treated L6 myotubes (c, d, e). The myotubes were treated with $5 \mathrm{mg} / \mathrm{ml}$ of EWH or $100 \mu \mathrm{M}$ of IRW for $2 \mathrm{~h}$ followed by treatment with $5 \mathrm{ng} / \mathrm{ml}$ of TNF- $\alpha$ for $24 \mathrm{~h}$. L6 myotubes were preincubated in KHH buffer for $2 \mathrm{~h}$. They were then

activation of IRS-1 through increased phosphorylation of serine residue of IRS-1, while decreased phosphorylation of tyrosine residue with respect to the untreated cells (Fig. 2c, d). Moreover, TNF- $\alpha$ resulted in subsequent deactivation of Akt (Fig. 2e). Thus, we next assessed the effect of EWH or IRW on IRS-1 and Akt phosphorylation in TNF- $\alpha$-treated L6 cells. The treatment of EWH or IRW increased the phosphorylation level of tyrosine residue (Fig. 2c) of IRS-1, whereas the phosphorylation of serine residue was significantly decreased (Fig. 2d) in comparison with TNF- $\alpha$ alone. Furthermore, the phosphorylation of Akt was also significantly restored by either EWH or IRW (Fig. 2e). Taken together, these data demonstrate that normalized insulin-signaling pathway by both EWH incubated in $\mathrm{KHH}$ buffer containing $11 \mathrm{mM}$ glucose without or with $100 \mathrm{~nm}$ of insulin for $30 \mathrm{~min}$. The cells were lysed and western blotting of the lysates was performed with antibodies against p-Akt (a, b, e), total Akt (a, b, e), p-IRS-1 tyr 632 (c), p-IRS-1 Ser 307 (d), total IRS-1 (c, d), and $\alpha$-tubulin (loading control). A set of representative images is shown. Data are presented as mean \pm SEM of three independent experiments. Single asterisk indicates $p<0.05$ as compared to insulin alone. Double asterisk indicates $p<0.05$ as compared to insulin and TNF- $\alpha$

and IRW is a contributing factor to the improved glucose uptake in TNF- $\alpha$-induced insulin resistance.

\section{Effect of EWH or IRW on GLUT4 translocation in TNF a-treated L6 myotubes}

Having observed that both EWH and IRW improve insulinstimulated glucose uptake as well as insulin-signaling pathway, we next evaluated the effect of EWH or IRW on GLUT4 translocation in TNF- $\alpha$-treated L6 cells using two different experiment techniques. First, we detected the GLUT4 abundance in L6 myotubes using immunofluorescence. As shown in Fig. 3a, red fluorescence (top) shows cellular localization of GLUT4, while DAPI+ GLUT4 (down) indicates merging 

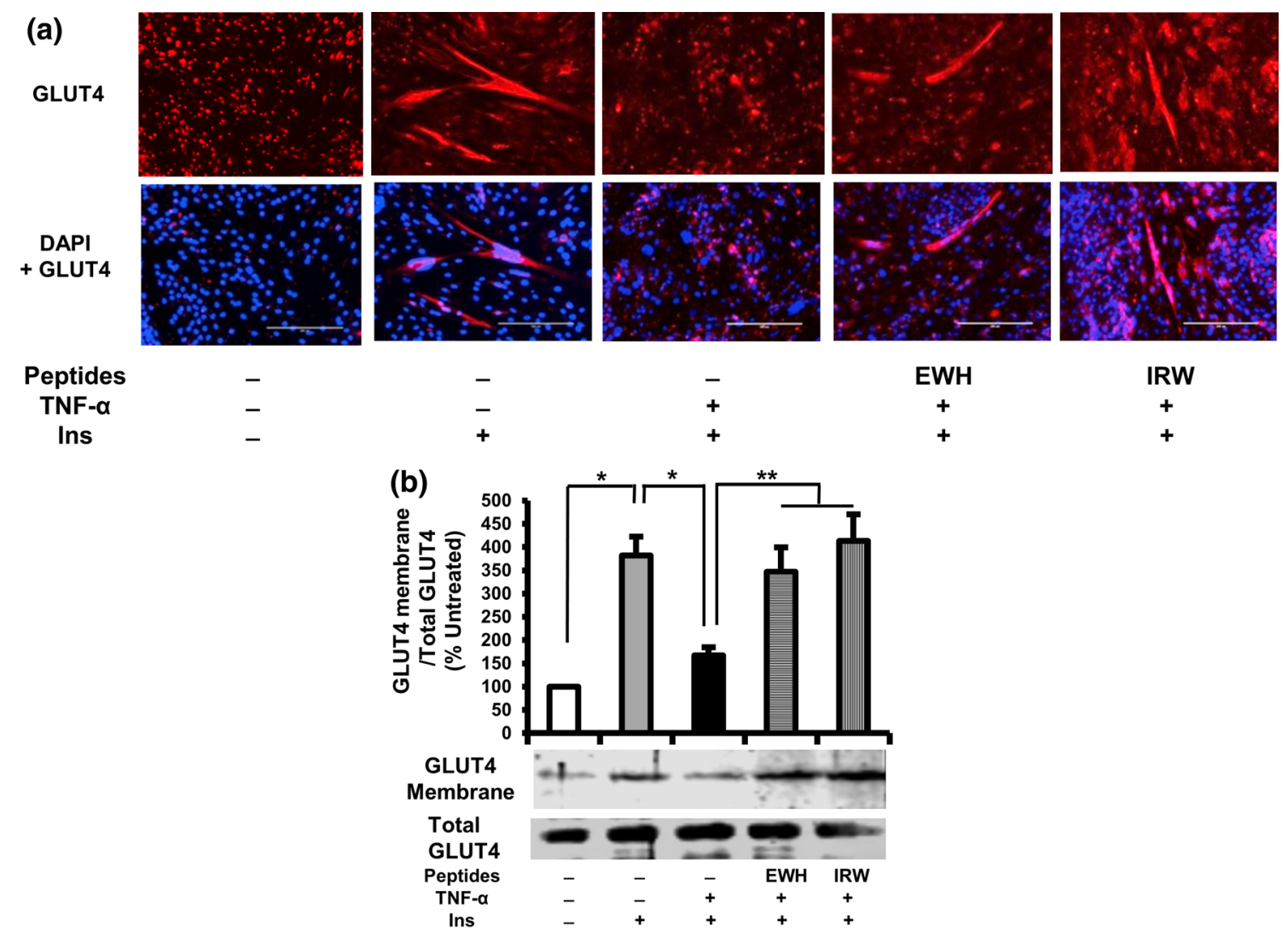

Fig. 3 Effects of EWH or IRW on GLUT4 translocation in TNF- $\alpha$ treated L6 myotubes. The myotubes were treated with $5 \mathrm{mg} / \mathrm{ml}$ of EWH or $100 \mu \mathrm{M}$ of IRW for $2 \mathrm{~h}$ followed by treatment with $5 \mathrm{ng} / \mathrm{ml}$ of TNF- $\alpha$ for $24 \mathrm{~h}$. L6 myotubes were preincubated in KHH buffer for $2 \mathrm{~h}$. They were then incubated in KHH buffer containing $11 \mathrm{mM}$ glucose without or with $100 \mathrm{~nm}$ of Insulin for $30 \mathrm{~min}$ (a). GLUT4 localization was detected using immunofluorescence technique and western blotting. Cellular localization of GLUT4 proteins is shown

of GLUT4 and nuclei. The robust decrease in the GLUT4 level was detected in TNF- $\alpha$ treated cells as compared to insulin-treated one. The treatment of IRW or EWH improved the defects in GLUT4 abundance on cellular membrane in TNF- $\alpha$-treated cells. This effectiveness of immunofluorescence result was confirmed by western blot (Fig. 3b). The result showed that both EWH and IRW significantly elevated the expression of GLUT4 on plasma membrane in comparison with TNF- $\alpha$-treated cells, indicating the possibility that both EWH and IRW re-established defective GLUT4 translocation in TNF- $\alpha$-treated cells.

\section{Effect of EWH or IRW on p38 MAPK and JNK1/2 activation in TNF-a-treated L6 myotubes}

Extensive studies in different diabetic animal models and cells unambiguously showed that TNF- $\alpha$ activated $\mathrm{p} 38$ and JNK1/2, resulting in interruption of insulin signaling [16, 17]. We, therefore, sought to examine whether the effect in red fluorescence (top) and merged image is also shown (below). A representative set of images from three independent experiments is shown. b Membranes were separated from the cells. The expression of GLUT4 was tested by western blot. Each value represents the mean \pm SEM of three independent experiments. Single asterisk indicates $p<0.05$ as compared to insulin alone. Double asterisk indicates $p<0.05$ as compared to insulin and TNF- $\alpha$

of EWH or IRW is associated with the phosphorylation of p38MAPK and JNK1/2. While TNF- $\alpha$ treatment significantly increased the activation of both $\mathrm{p} 38$ and JNK $1 / 2$ in the presence of insulin as compared to those in untreated cells (Fig. 4 a, b), only the phosphorylation of JNK1/2 was increased by TNF- $\alpha$ in the absence of insulin (Fig. 4d, e). However, pretreatment with EWH and IRW diminished the activation of p38 (Fig. 4a), as well as JNK1/2 (Fig. 4b, d). These results indicate that the prevention of insulin resistance by EWH and IRW may stem from inhibiting p38 and JNK1/2 activities.

\section{Discussion}

Insulin resistance is one of the main defining clinical features in metabolic syndrome. Given that skeletal muscle is characterized as a major tissue for insulin-mediated glucose disposal, skeletal muscle cell is an appropriate model to 
Fig. 4 Effects of EWH or IRW on $\mathrm{p} 38$ and JNK $1 / 2$ activation in TNF- $\alpha$-treated L6 myotubes. The myotubes were treated with $5 \mathrm{mg} / \mathrm{ml}$ of EWH or $100 \mu \mathrm{M}$ of IRW for $2 \mathrm{~h}$ followed by the treatment with $5 \mathrm{ng} / \mathrm{ml}$ of TNF- $\alpha$ for $0.5 \mathrm{~h}$. The cells were lysed and western blotting of the lysates was performed with antibodies against p-p38 (a, c), p-38 (a, c), p-JNK1/2 $(\mathbf{b}, \mathbf{d}), \mathrm{JNK} 1 / 2(\mathbf{b}, \mathbf{d})$, and $\alpha$-tubulin (loading control). A set of representative images was shown. Data were presented as mean \pm SEM of three independent experiments. Single asterisk indicates $p<0.05$ as compared to insulin alone. Double asterisk indicates $p<0.05$ as compared to insulin and TNF- $\alpha .{ }^{\#} p<0.05$ as compared to TNF- $\alpha$ alone
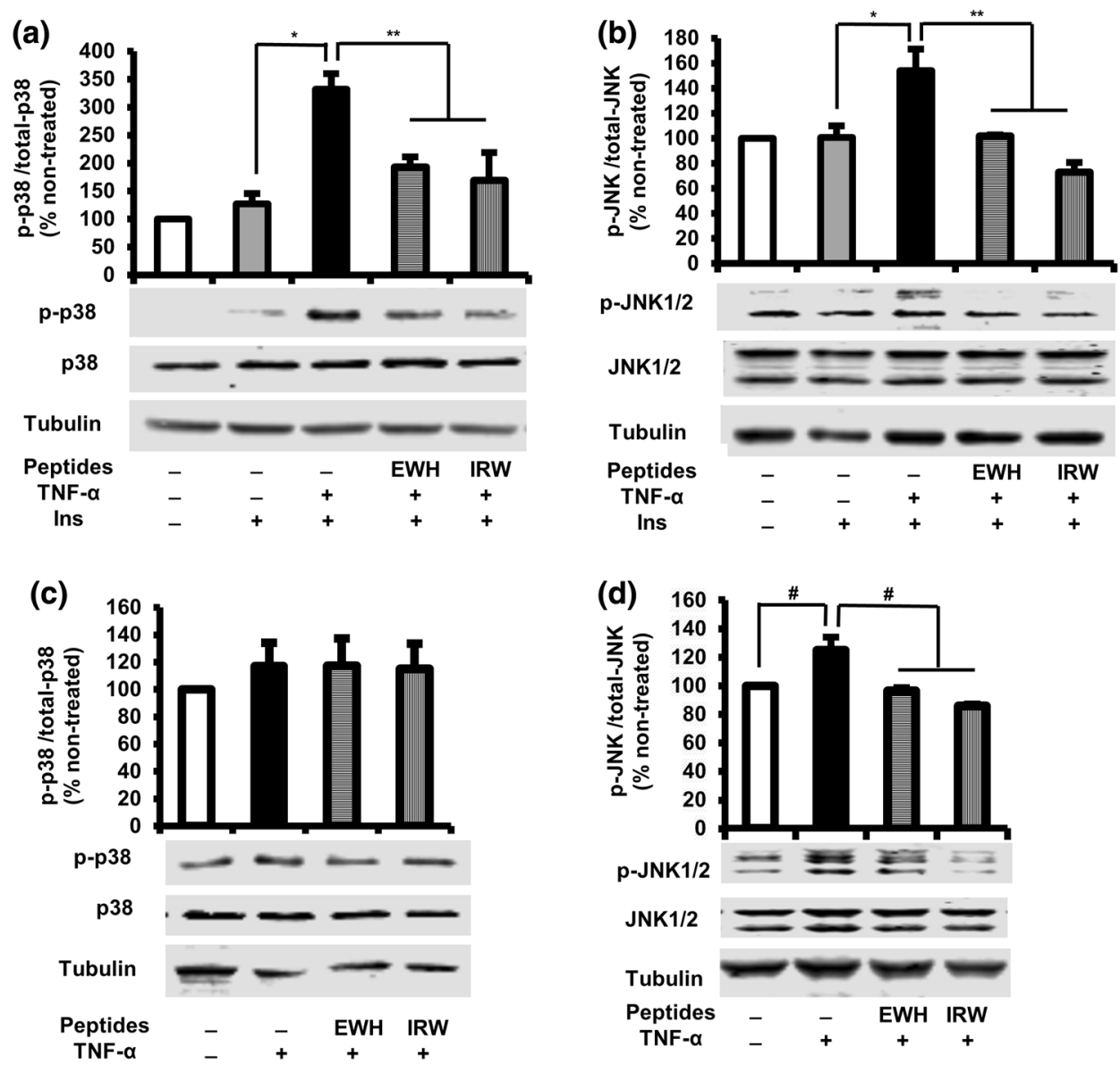

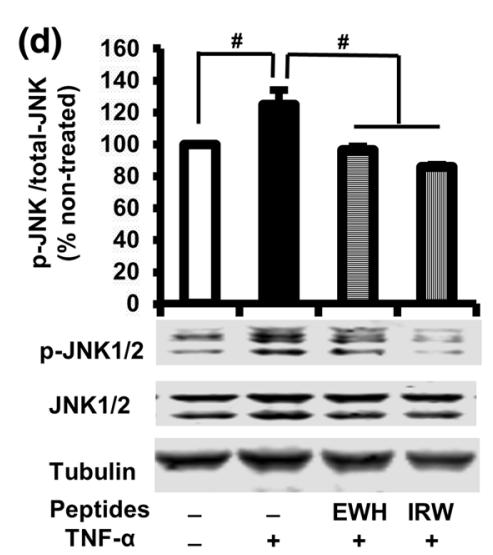

explore natural food component with potential application against insulin resistance. In the current study, we showed that both EWH and IRW can improve insulin resistance in TNF- $\alpha$-treated L6 skeletal muscle cells. TNF- $\alpha$ treatment suppressed insulin-stimulated glucose uptake via the disruption of insulin signaling and GLUT4 translocation, while incubating EWH or IRW $2 \mathrm{~h}$ prior to TNF- $\alpha$ significantly restored these defects. The mechanism underlying was potentially through the reduction of phosphorylation of p38 and JNK $1 / 2$.

It has become increasingly evident over the last decade that chronic inflammation is major contributor to the development and progression of insulin resistance $[37,38]$. The results from the clinical studies have revealed a clear association between the pro-inflammatory signaling pathway and insulin resistance. Elevated levels of pro-inflammatory biomarkers such as TNF- $\alpha$, interleukin-6 (IL-6) and interleukin-8 (IL-8), and C-reactive protein (CRP) have all been reported in various insulin resistance states [39-43]. Animal and human studies also support the link between TNF- $\alpha$ and insulin resistance $[15,17]$. Hotamisligil et al. have reported that obese mice genetically deficient of TNF- $\alpha$ or its receptor ameliorated glucose homeostasis [15]. In addition, phosphorylation of Tyr residue in p-IRS and GLUT4 expression in skeletal muscle was increased compared to obese-TNF+/+ group. TNF- $\alpha$ infusion for $4 \mathrm{~h}$ decreased peripheral insulinmediated glucose uptake, without influencing endogenous gluconeogenesis from the liver [17]. Thus, inhibition of the action of TNF- $\alpha$ contributes to improved insulin sensitivity. Interestingly, in this study, we observed that pre-incubation of EWH or IRW for $2 \mathrm{~h}$ recovered TNF- $\alpha$ impaired glucose uptake and GLUT4 abundance on cell membrane. In addition, both EWH and IRW improved IRS-1 and Akt activation, which suggests the possibility in insulin sensitivity enhancement.

The underlying mechanism of TNF- $\alpha$-induced insulin resistance has been reported to mediate through the inflammatory signaling pathway including the activation of three MAPKs, p38 [16], JNK1/2, and ERK1/2 [17]. It is well recognized that MAPK signaling is required for maintaining normal metabolic condition, but the excessive activation of MAPKs is associated with inflammatory diseases including obesity and diabetes [44].

Over-expressed MKK6/3-p38/MAPK in L6 myotubes was reported to deteriorate the action of GLUT4 via downregulation of GLUT4 gene expression [45], whereas knockdown MAP4K4, the upstream kinase of ERK1/2 and JNK, inhibits TNF- $\alpha$-induced insulin resistance [46]. Collectively, 
these data highlight that increased MAPK activity plays a significant role in the pathogenesis of insulin resistance in skeletal muscle. Our current study showed that TNF- $\alpha$ treatment increased the phosphorylation of p38 and JNK1/2, but significantly attenuated by EWH or IRW further acknowledging the involvement of MAPKs in their underlying mechanism.

IRW was initially identified as an ACE-inhibitory peptide [24]. While it showed anti-hypertensive effect in spontaneously hypertensive rats (SHR), interestingly, it also decreased pro-inflammatory/oxidative stress markers [25]. In particular, IRW exhibited anti-inflammatory and antioxidant effect in human umbilical vein endothelial cells (HUVECs) by reduction of TNF- $\alpha$-induced superoxide generation $[27,28]$. Our results suggest the possibility that specific ACE-inhibitory peptides derived from food protein might possess various capacities to expand their application in the disorders associated with oxidative stress and inflammation mechanism.

While EWH and IRW showed similar effect and underlying mechanism in our current study, further investigation in vivo will be required to confirm the efficacy of EWH after the digestion. Furthermore, considering TNF- $\alpha$ is an important contributing factor to the development of insulin resistance, additional studies are warranted to determine the precise role of EWH and IRW in relation with the action of increased circulating TNF- $\alpha$ in insulin resistance animals.

In conclusion, the present study shows, for the first time, that EWH processed by thermolysin and pepsin, and egg white-derived tripeptide, IRW, improves impaired insulin sensitivity by down-regulating the activation of p38 and JNK1/2 in TNF- $\alpha$-treated skeletal muscle cells. Our results provide an important insight for further investigating of food protein hydrolysates and peptides as a novel therapeutic alternation against metabolic syndrome and help to illustrate their mechanism of action.

Acknowledgements This work is supported by research grants from the Alberta Livestock and Meat Agency, (ALMA), Egg Farmers of Canada, and the Natural Sciences and Engineering Research Council of Canada (NSERC).

\section{Compliance with ethical standards}

Conflict of interest There is no conflict of interest.

Open Access This article is distributed under the terms of the Creative Commons Attribution 4.0 International License (http://creativeco mmons.org/licenses/by/4.0/), which permits unrestricted use, distribution, and reproduction in any medium, provided you give appropriate credit to the original author(s) and the source, provide a link to the Creative Commons license, and indicate if changes were made.

\section{References}

1. Moller DE, Kaufman KD (2005) Metabolic syndrome: a clinical and molecular perspective. Annu Rev Med 56:45-62

2. Reaven GM (2005) The insulin resistance syndrome: definition and dietary approaches to treatment. Annu Rev Nutr 25:391-406

3. Tabish SA (2007) Is diabetes becoming the biggest epidemic of the twenty-first century? Int J Health Sci (Qassim) 1(2):V-VIII

4. Reaven GM (2005) Why syndrome X? From Harold Himsworth to the insulin resistance syndrome. Cell Metab 1(1):9-14

5. Lillioja S, Mott DM, Howard BV, Bennett PH, Yki-Järvinen H, Freymond D, Nyomba BL, Zurlo F, Swinburn B, Bogardus C (1988) Impaired glucose tolerance as a disorder of insulin action. Longitudinal and cross-sectional studies in Pima Indians. N Engl J Med 318(19):1217-1225

6. Warram JH, Martin BC, Krolewski AS, Soeldner JS, Kahn CR (1990) Slow glucose removal rate and hyperinsulinemia precede the development of type II diabetes in the offspring of diabetic parents. Ann Intern Med 113:909-915

7. DeFronzo RA, Tripathy D (2009) Skeletal muscle insulin resistance is the primary defect in type 2 diabetes. Diabetes Care 32(2):S157-S163

8. Saltiel AR, Kahn CR (2011) Insulin signalling and the regulation of glucose and lipid metabolism. Nature 414:799-806

9. Thiebaud D, Jacot E, DeFronzo RA, Maeder E, Jequier E, Felber JP (1982) The effect of graded doses of insulin on total glucose uptake, glucose oxidation, and glucose storage in man. Diabetes 31(11):957-963

10. Shulman GI (2000) Cellular mechanisms of insulin resistance. J Clin Invest 106:171-176

11. William PC, Jaswinder KS (2008) TNF- $\alpha$ and adipocyte biology. FEBS Lett 582(1):117-131

12. Zinman B, Hanley AJ, Harris SB, Kwan J, Fantus IG (1999) Circulating tumor necrosis factor- $\alpha$ concentrations in a native Canadian population with high rates of type 2 diabetes mellitus. J Clin Endocrinol Metab 84:272-278

13. Saghizadeh M, Ong JM, Garvey WT, Henry RR, Kern PA (1996) The expression of TNF- $\alpha$ by human muscle. Relationship to insulin resistance. J Clin Invest 97:1111-1116

14. Hotamisligil GS, Arner P, Caro JF, Atkinson RL, Spiegelman BM (1995) Increased adipose tissue expression of tumor necrosis factor- $\alpha$ in human obesity and insulin resistance. J Clin Invest 95:2409-2415

15. Uysal KT, Wiesbrock SM, Marino MW, Hotamisligil GS (1997) Protection from obesity-induced insulin resistance in mice lacking TNF- $\alpha$ function. Nature 389:610-614

16. de Alvaro C, Teruel T, Hernandez R, Lorenzo M (2004) Tumour necrosis factor $\alpha$ produces insulin resistance in skeletal muscle by activation of inhibitor kappaB kinase in a p38 MAPK-dependent manner. J Biol Chem 279:17070-17078

17. Plomgaard P, Bouzakri K, Krogh-Madsen R, Mittendorfer B, Zierath JR, Pedersen BK (2005) Tumor necrosis factor- $\alpha$ induces skeletal muscle insulin resistance in healthy human subjects via inhibition of Akt substrate 160 phosphorylation. Diabetes 54(10):2939-2945

18. Kain V, Kapadia B, Viswakarma N, Seshadri S, Prajapati B, Jena PK, Teja Meda CL, Subramanian M, Kaimal Suraj S, Kumar ST, Prakash Babu P, Thimmapaya B, Reddy JK, Parsa KV, Misra $\mathrm{P}$ (2015) Co-activator binding protein PIMT mediates TNF- $\alpha$ induced insulin resistance in skeletal muscle via the transcriptional down-regulation of MEF2A and GLUT4. Sci Rep 5:15197

19. Rosenzweig T, Braiman L, Bak A, Alt A, Kuroki T, Sampson SR (2002) Differential effects of tumor necrosis factor-on protein kinase $\mathrm{C}$ isoforms $\alpha$ and deltha mediate inhibition of insulin receptor signaling. Diabetes 51:1921-1930 
20. Steinberg GR, Michell BJ, van Denderen BJ, Watt MJ, Carey AL, Fam BC, Andrikopoulos S, Proietto J, Görgün CZ, Carling D, Hotamisligil GS, Febbraio MA, Kay TW, Kemp BE (2006) Tumor necrosis factor $\alpha$-induced skeletal muscle insulin resistance involves suppression of AMP-kinase signaling. Cell Metab 4:465-474

21. Li-Chan ECY (2015) Bioactive peptides and protein hydrolysates: research trends and challenges for application as nutraceuticals and functional food ingredients. Curr Opin Food Sci 1:28-37

22. Majumder K, Wu J (2010) A new approach for identification of novel antihypertensive peptides from egg proteins by QSAR and bioinformatics. Food Res Int 43:1371-1378

23. Majumder K, Wu J (2011) Purification and characterization of angiotensin I converting enzyme (ACE) inhibitory peptides derived from enzymatic hydrolysate of ovotransferrin. Food Chem 126:1614-1619

24. Majumder K, Chakrabarti S, Morton JS, Panahi S, Kaufman S, Davidge ST, Wu J (2015) Egg-derived ACE-inhibitory peptides IQW and LKP reduce blood pressure in spontaneously hypertensive rats. J Funct Foods 13:50-60

25. Majumder K, Chakrabarti S, Morton JS, Panahi S, Kaufman S, Davidge ST, Wu J (2013) Egg-derived tri-peptide IRW exerts antihypertensive effects in spontaneously hypertensive rats. PLoS One 8(11):e82829

26. Huang W, Chakrabarti S, Majumder K, Jiang Y, Davidge ST, Wu J (2010) Egg-derived peptide IRW Inhibits TNF- $\alpha$-induced inflammatory response and oxidative stress in endothelial cells. J Agric Food Chem 58:10840-10846

27. Majumder K, Chakrabarti S, Davidge ST, Wu J (2013) Structure and activity study of egg protein ovotransferrin derived peptides (IRW and IQW) on endothelial inflammatory response and oxidative stress. J Agric Food Chem 61:2120-2129

28. Majumder K, Liang G, Chen Y, Guan L, Davidge ST, Wu J (2015) Egg ovotransferrin-derived ACE inhibitory peptide IRW increases ACE2 but decreases proinflammatory genes expression in mesenteric artery of spontaneously hypertensive rats. Mol Nutr Food Res 59:1735-1744

29. Liao W, Chakrabarti S, Davidge ST, Wu J (2016) Modulatory effects of egg white ovotransferrin-derived tripeptide IRW (IleArg-Trp) on vascular smooth muscle cells against angiotensin II stimulation. J Agric Food Chem 64(39):7342-7347

30. Son M, Catherine BC, Wu J (2018) Egg white ovotransferrinderived ACE inhibitory peptide ameliorates angiotensin II-stimulated insulin resistance in skeletal muscle cells. Mol Nutr Food Res. https://doi.org/10.1002/mnfr.201700602

31. Jahandideh F, Chakrabarti S, Majumder K, Li Q, Panahi S, Morton JS, Davidge ST, Wu J (2016) Egg white protein hydrolysate reduces blood pressure, improves vascular relaxation and modifies aortic angiotensin II receptors expression in spontaneously hypertensive rats. J Funct Foods 27:667-673

32. Jahandideh F, Chakrabarti S, Sandra T. Davidge ST, Wu J (2017) Egg white hydrolysate shows insulin mimetic and sensitizing effects in 3T3-F442A pre-adipocytes. PLoS One 12(10):e0185653
33. Ochiai M, Kuroda T, Matsuo T (2014) Increased muscular triglyceride content and hyperglycemia in Goto-Kakizaki rat are decreased by egg white hydrolysate. Int J Food Sci Nutr 65(4):495-501

34. Mitsumoto Y, Burdett E, Grant A, Klip A (1991) Differential expression of the GLUT1 and GLUT4 glucose transporters during differentiation of L6 muscle cells. Biochem Biophys Res Commun 175:652-659

35. Son MJ, Minakawa M, Miura Y, Yagasaki K (2013) Aspalathin improves hyperglycemia and glucose intolerance in obese diabetic ob/ob mice. Eur J Nutr 52(6):1607-1619

36. Ha BG, Nagaoka M, Yonezawa T, Tanabe R, Woo JT, Kato H, Chung UI, Yagasaki K (2012) Regulatory mechanism for the stimulatory action of genistein on glucose uptake in vitro and in vivo. J Nutr Biochem 23:501-509

37. de Luca C, Jerrold MO (2008) Inflammation and Insulin Resistance. FEBS Lett 582(1):97-105

38. Esser N, Legrand-Poels S, Piette J, Scheen AJ, Paquot N (2014) Inflammation as a link between obesity, metabolic syndrome and type 2 diabetes. Diabetes Res Clin Pract 105(2):141-150

39. Roytblat L, Rachinsky M, Fisher A, Greemberg L, Shapira Y, Douvdevani A, Gelman S (2000) Raised interleukin-6 levels in obese patients. Obes Res 8:673-675

40. Straczkowski M, Dzienis-Straczkowska S, Stepien A, Kowalska I, Szelachowska M, Kinalska I (2002) Plasma interleukin-8 concentrations are increased in obese subjects and related to fat mass and tumor necrosis factor- $\alpha \alpha$ system. J Clin Endocrinol Metab 87:4602-4606

41. Hotamisligil GS, Spiegelman BM (1994) Tumor necrosis factor $\alpha \alpha$ : a key component of the obesity diabetes link. Diabetes 43:1271-1278

42. Sartipy P, Loskutoff DJ (2003) Monocyte chemoattractant protein 1 in obesity and insulin resistance. PNAS 100:7265-7270

43. Miyazaki Y, Pipek R, Mandarino LJ, DeFronzo RA (2003) Tumor necrosis factor $\alpha$ and insulin resistance in obese type 2 diabetic patients. Int J Obes (Lond) 27:88-94

44. Helmuth G, Susann K, Arne I, Romeo R (2010) MAPK signalling in cellular metabolism: stress or wellness? EMBO Rep 11(11):834-840

45. Fujishiro M, Gotoh $Y$, Katagiri H, Sakoda H, Ogihara T, Anai M, Onishi Y, Ono H, Funaki M, Inukai K, Fukushima Y, Kikuchi M, Oka Y, Asano T (2001) MKK6/3 and p38 MAPK pathway activation is not necessary for insulin-induced glucose uptake but regulates glucose transporter expression. J Biol Chem 276(23):19800-19806

46. Helmut G, Susann K, Arne I, Romeo R, Bouzakri K, Zierath JR (2007) MAP4K4 gene silencing in human skeletal muscle prevents tumour necrosis factor $\alpha \alpha$-induced insulin resistance. J Biol Chem 282:7783-7789 